Research Article

\title{
Static and Dynamic Load Tests of Shaft and Base Grouted Concrete Piles
}

\author{
Jialin Zhou, ${ }^{1}$ Xin Zhang, ${ }^{2}$ Hongsheng Jiang, ${ }^{2}$ Chunhao Lyu, ${ }^{1}$ and Erwin $\mathrm{Oh}^{1}$ \\ ${ }^{1}$ Griffith School of Engineering, Griffith University, Gold Coast, QLD, Australia \\ ${ }^{2}$ School of the Civil Engineering, Shandong Jianzhu University, Jinan, Shandong, China \\ Correspondence should be addressed to Jialin Zhou; jialin.zhou@griffithuni.edu.au
}

Received 3 May 2017; Accepted 20 September 2017; Published 31 December 2017

Academic Editor: Hossein Moayedi

Copyright (c) 2017 Jialin Zhou et al. This is an open access article distributed under the Creative Commons Attribution License, which permits unrestricted use, distribution, and reproduction in any medium, provided the original work is properly cited.

This paper examines shaft and base grouted concrete piles by conducting vertical static load tests (SLTs) and dynamic load tests. Three concrete piles with shaft and base grouting, with base grouting only, and without grouting techniques were selected, and compressive SLTs were conducted. Two piles with grouting were also assessed with dynamic load tests. Another two uplift SLTs were conducted to one shaft and base grouted pile and one pile without grouting. Traditional presentations were provided to check whether the bored piles reached the design requirement. Interpretations of test results were also provided to determine the ultimate pile capacity. Results from these 5 SLT programs indicated that double-tangent and DeBeer's methods are close to each other, and Chin's method overestimates the pile capacity. Comparison of the results from the SLTs and dynamic load tests shows that the results from Chin's method are close to dynamic results, and Mazurkiewicz's method overestimates for friction resistance. The results also demonstrate that base and shaft grouted pile and base grouted pile increase by $9.82 \%$ and $2.89 \%$ in compressive capacity, respectively, and compared to the uplift SLTs; there is a $15.7 \%$ increment in pile capacity after using base and shaft grouting technology.

\section{Introduction}

With the soaring requirement of building space in metropolises, high-rise building development is indispensable, and thus deep piles are imperative. Pile length can range from $20 \mathrm{~m}$ to $60 \mathrm{~m}$ due to large loads from upper structures needing to be transferred into soils. Apart from designing long pile foundations, which can provide more friction resistance, grouting technology is also a good way to increase the ultimate bearing capacity. Sometimes this technology is also applied in construction of large diameter deep piles. One example of this is the two bored piles with depths of $65 \mathrm{~m}$ and $91 \mathrm{~m}$ tested in western Bangladesh with test results showing increments of end bearing and shaft baring capacity and decreases of base settlements [1]. Another example is a skyscraper project in London, where the diameters of piles were $2.4 \mathrm{~m}$ with a length of $63 \mathrm{~m} \mathrm{[2]}$.

Compared to bored piles, precast concrete piles are frequently more costly [3]. However, during the process of cast-in-situ construction, some soil deposits can remain at the base area after drilling the hole. The remaining deposit, which is accumulated by collapse during drilling, will lead to a decrease in the end resistance capacity of the pile and an increase of pile settlement. This potential for reduced pile capacity was affirmed during construction in Taiyuan City, China, where capacities were much lower than the designed requirement tested by static load tests [4]. Furthermore, the drilling operation can loosen the soil underneath the base of the bored hole which can also lead to excessive working load settlement. Engineers nowadays use admixtures like polymeric slurry or bentonite as a support to avoid the collapse of soils during drilling construction; this, however, creates other issues. The use of these materials may lead to capacity decrease of pile shafts because these admixtures create a layer between soil and pile when combined with soil and water, which consequently leads to a decrease of friction resistance of the pile. It has been reported that this admixture layer or composite layer can decrease the pile bearing capacity by $30 \%$ to $40 \%$ [5].

Such limitations, however, can be addressed with a base and shaft grouting technique (or postgrouting technique). This construction technology of cast-in-situ piles started in 


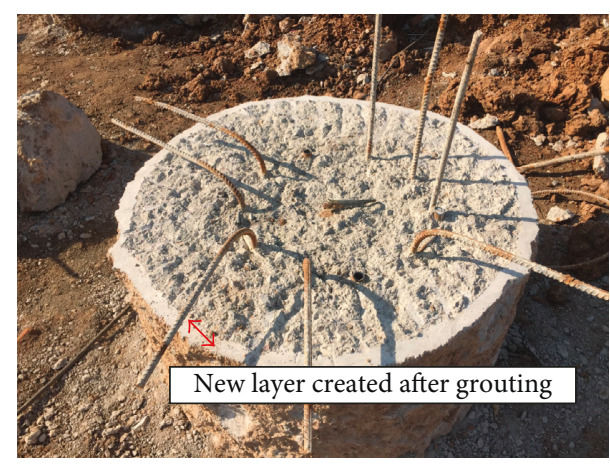

Figure 1: Postgrouted concrete pile.

the mid of 1970s. It can generally be categorized into a flat jack system which consists of grout delivery pipes connected to a steel plate with a rubber membrane and a sleeve-port system that consists of 2-4 U-tubes installed at the bottom of the pile. This U-tube is covered by rubber and can be arranged in various configurations [6]. Cement admixture which is blended into various ratios is the popular material for grouting. It is injected to the pile toe through U-tubes under high pressure, consequently restoring the original density of the base soil and reducing the settlement of the pile when loading transfers from the upper structure [3]. It is worth noting that, due to high pressure, partial cement admixture will force the admixture layers upwards, which leads to a recovering and improvement of shaft resistance around the pile. As shown in Figure 1, there is, therefore, a new cement layer created after the grouting is applied.

Analytical analysis methods can predict the ultimate capacity of bored and driven piles, but they are only used for primary design. In order to obtain pile capacity, the most popular methods are static load tests because they can provide the most accurate results from piles [7]. This test system includes the hydraulic jacks which are used for load provision reference beams and a measuring system. By conducting compressive/uplift/lateral static load tests, the pile displacement can be determined under corresponding loads (axial compression, tension, or lateral loads).

Field geotechnical testing includes dynamic load tests, compressive and uplift static load tests, and O-Cell tests [8]. Several compressive static load tests of base grouted piles have been conducted. Due to grouting being more popular in granular soils, some researchers have focused on the soil type effect and load transfer mechanism $[9,10]$. Other researchers have concentrated on the construction process and capacity improvements $[12,13]$. Recent tests and numerical simulations have shown that the postgrouted concrete piles can increase twice the ultimate capacity of defected piles and increase about $20 \%$ compared to normal piles [14]. Compared to grouting piles and nongrouting piles, results have shown that grouting could increase 18-19\% of shaft resistance and $63 \%$ of base resistance [15]. Through tests on seven piles, Zhang et al. [16] have pointed out that posttechnology has had an enhancing effect on shaft and base resistance, but the increase in pile capacity was affected by slenderness ratio. For the research of grouting techniques on precast piles, a recent experimental and FEM study has proposed the capacity estimation and method of grout pressure [17]. Several other projects with application of base grouting techniques have been provided by Sinnreich and Simpson [18]; however, these results are ambivalent because some projects illustrate increase of grouted pile capacity and some projects do not.

A large number of investigations have been carried out to obtain the behaviors of piles under uplift loading. Some researchers have focused on the behaviors of different types of piles such as precast piles, cast-in-situ bored piles, and steel pipe piles [19-21]. Other researchers have concentrated on the uplift behavior of piles in cohesionless soil [22-24]. Through experimental tests, a study revealed that pile behavior under uplift force depends mainly on pile embedment depth-to-diameter ratio and soil properties [22]. A further study investigated pile behavior under combined uplift and lateral loading [25]. Recent research on belled and multibelled piles in dry loose sand has also been conducted, with uplift resistance being found to increase up to $60 \%$ in comparison with straight piles [26]. The investigations of base and shaft grouted uplift field tests, capacity improvement, and load transfer mechanism, however, remain limited. This paper is based on the work of Zhou et al. [27] with additional analysis. Zhou et al. [27] has reported the static load test of postgrouted pile, whereas this paper examines both static and dynamic load tests of piles on the same case study.

In order to determine the load transfer behavior of piles under compressive and uplift static load tests, wire vibration strain-reinforced bars are commonly used. The disadvantage of these strain gauge applications is that labor is required and it is time consuming. A project may be delayed in order to avoid the damage of strain gauges during transference of the steel cages, pouring of concrete, and breaking the pile tip. With developing technology, dynamic load tests can provide good results with load transfer information. Compared to static load tests, Pile Driving Analyzer (PDA) tests are relatively cheaper and time saving [28]. A popular program is the Case Pile Wave Analysis Program (CAPWAP). The bearing capacity and the distribution along the pile shaft and toe as well as simulated static load tests can be determined by matching signals obtained from the dynamic load tests [29]. The strain sensors and accelerometers are used to measure the force and velocity inside the pile after applying load provided by a hammer. The load transfer mechanism can be obtained when the matched wave approaches the acquired wave onsite. Investigations of driven polymeric piles using dynamic load tests were conducted in Elizabeth, New Jersey, providing load testing installation and comparison between static and dynamic load tests. That paper also focused on the possible application of plastic piles under axial loading [30].

As mentioned above, there is limited research on compressive and uplift loaded grouting piles. This paper, therefore, aims to investigate the ultimate capacity of postgrouted concrete piles under compressive and uplift loading and load transfer mechanism by static load tests. By comparing the compressive capacity among piles with shaft and base grouting, base grouting only, and no grouting, the increment 
TABLE 1: Generalized soil profiles.

\begin{tabular}{|c|c|c|c|c|c|c|}
\hline Soil layers & Depth $(\mathrm{m})$ & Average $N$ value & $\Gamma\left(\mathrm{kN} / \mathrm{m}^{3}\right)$ & $C(\mathrm{kPa})$ & $\varphi^{\prime}\left({ }^{\circ}\right)$ & Fak $(\mathrm{kPa})$ \\
\hline Miscellaneous fill & 2.61 & 5 & 19.0 & 5.0 & 10.0 & - \\
\hline Silty clay & 3 & 7 & 18.9 & 16.6 & 19.7 & 150 \\
\hline Gravel & 3.5 & 21 & 20.0 & 5.0 & 30.0 & 260 \\
\hline Silty clay & 3.5 & 21 & 19.3 & 18.2 & 16.8 & 200 \\
\hline Gravel & 5.5 & 22 & 20.0 & 8.0 & 30.0 & 280 \\
\hline Residual soil & 5 & 23 & 18.0 & 5.0 & 28.0 & 200 \\
\hline Weathered diorite & 4 & 41 & 18.5 & 10.0 & 30.0 & 240 \\
\hline Highly weathered diorite & 1.7 & 43 & 25.5 & 12.0 & 48.0 & 450 \\
\hline Bearing stratum & N/A & $>50$ & 28.8 & 12.0 & 54.0 & 2000 \\
\hline
\end{tabular}

of pile capacity by the grouting technique is determined. The increment of uplift capacity by grouting is also observed by uplift static load tests. In addition, to interpret the static load tests, double-tangent, DeBeer's, Chin's, and Mazurkiewicz's methods are provided [31]. This paper also provides dynamic load tests for load transfer mechanism analysis. It should be noted that this paper investigated the piles' behavior and shaft mechanisms under different grouting techniques, which has not been reported based on results' comparison between static load tests and dynamic load tests.

\section{Subsurface Condition}

The project aims to build a 22 -level office building at a height of $82.95 \mathrm{~m}$, with a construction area of $50.8 \mathrm{~m} \times 42.2 \mathrm{~m}$. This construction site is located in Jinan City, China. The subsurface exploration was determined through laboratory and in situ tests. The in situ tests of standard penetration tests (SPT) and cone penetration tests (CPT) and laboratory tests of consolidation tests, direct shear tests, and triaxial tests were conducted based on the Chinese Standard for Soil Tests Method code and the Investigation of Geotechnical Engineering code, respectively.

A hammer with a weight of $63.5 \mathrm{~kg}$ was selected for SPT and CPT tests, and the counts for $300 \mathrm{~mm}$ and $100 \mathrm{~mm}$ penetrations were recorded as $N$ value and $N_{63.5}$ value, respectively (10 in situ tests, Clause 10.4 and 10.5). The soil classification was determined based on these $N$ values and was based on Clause 3.3 of Soil Classification [32]. Laboratory tests including consolidation shear test and triaxle tests (CU\& UU) were conducted for soil characteristics of specific gravity, relative density, porosity, void ratio, saturation ratio, water content, plastic limit, liquid limit, plasticity index, liquidity index, direct shear test, cohesion, and friction angle based on Clause 5, 8, 9, 13, 14, 16, and 18, respectively [33]. Based on the borehole logs, the simplified soil layers were then discovered as follows, with the properties of soil layers illustrated in Table 1:

(1) Miscellaneous fill: loose, containing gravel and rubble, diameter ranging from 2.0 to $7.0 \mathrm{~mm}$, and the average thickness of $2.61 \mathrm{~m}$

(2) Silty clay: medium stiff, yellowish with high plasticity, and the average thickness of $3.0 \mathrm{~m}$
(3) Gravel: medium dense and the average thickness of $3.5 \mathrm{~m}$

(4) Silty clay: medium stiff, low plasticity, and the average depth of $3.5 \mathrm{~m}$

(5) Gravel: medium dense with dark clay and the diameter of gravel ranging from $5.5 \mathrm{~m}$

(6) Residual soil: dense, containing iron and manganese oxides, and the average thickness of $5.0 \mathrm{~m}$

(7) Weathered diorite: medium to dense and the average depth of $4.0 \mathrm{~m}$

(8) Highly weathered diorite: medium to dense and the average thickness of $1.7 \mathrm{~m}$

(9) Bearing stratum: very dense, RQD of 40 , and the average strength of $10.65 \mathrm{MPa}$

This project required underground car parks, so the excavation construction started first with the depth of $9 \mathrm{~m}$. After the soil was removed, the in situ piles were cast and were surrounded by 4 layers. The compressive and uplift loaded piles of P51, P121, P126, P15, and P16 were adjacent to each other, so the soil condition was similar. The soil layers surrounding the piles were residual soil with thickness of $5 \mathrm{~m}$, weathered diorite with average thickness of $4 \mathrm{~m}$, highly weather diorite with average thickness of $1.7 \mathrm{~m}$, and bearing stratum.

\section{Pile Description}

Three and two concrete bored piles with label of P51, P121, P126, P15, and P16 were cast for conducting compressive and uplift static load tests, respectively. All these piles were made of the same concrete and reinforcement, with the same diameter and length (Tables 2 and 3), but the grouting technology used was different. Different to the base grouting, base and shaft grouting system contains a circular tube $(R=800 \mathrm{~mm})$ with an inside diameter of $5 \mathrm{~mm}$ and an additional shaft grouting pipe (Figure 2), which was welded to steel cages. This grouting tube was drilled with small holes with a spacing of $150 \mathrm{~mm}$ covered by a membrane which is used to prevent the fine sand blocking the grouting holes.

As depicted in Table 3, during the construction process, P126 was cast using base and shaft grouting technology, and P121 was cast using base grouting only. In order to 
TABLE 2: Information of tested piles.

\begin{tabular}{|c|c|c|c|c|c|c|}
\hline Steel bars & Dia. $(\mathrm{mm})$ & Type & Spacing $(\mathrm{mm})$ & $f_{y}(\mathrm{MPa})$ & Es (MPa) & $v$ \\
\hline Longitudinal & 14 & HRB 400 & N/A & 360 & 200,000 & 0.3 \\
\hline Stirrups, top $4 \mathrm{~m}$ & 8 & HRB400 & 100 & 360 & 200,000 & 0.3 \\
\hline Stirrups, other part & 8 & HRB400 & 200 & 360 & 200,000 & 0.3 \\
\hline Stiffening ring & 14 & HRB400 & 2000 & 360 & 200,000 & 0.3 \\
\hline
\end{tabular}

TABLE 3: Description of test piles.

\begin{tabular}{|c|c|c|c|c|c|c|}
\hline Pile label & Technology used & Types of tests & Length (m) & Diameter (m) & $\begin{array}{c}\text { Concrete } \\
\text { type }\end{array}$ & $\begin{array}{l}\text { Compressive } \\
\text { strength }(\mathrm{kPa})\end{array}$ \\
\hline P51 & No grouting & Compressive SLTs & 19.5 & 800 & C50 & 50 \\
\hline $\mathrm{P} 121$ & Base grouting & Compressive SLTs, dynamic load test & 19.5 & 800 & C50 & 50 \\
\hline P126 & Base and shaft grouting & Compressive SLTs, dynamic load test & 19.5 & 800 & C50 & 50 \\
\hline P15 & Base and shaft grouting & Uplift SLTs & 19.5 & 800 & $\mathrm{C} 50$ & 50 \\
\hline P16 & No grouting & Uplift SLTs & 19.5 & 800 & $\mathrm{C} 50$ & 50 \\
\hline
\end{tabular}

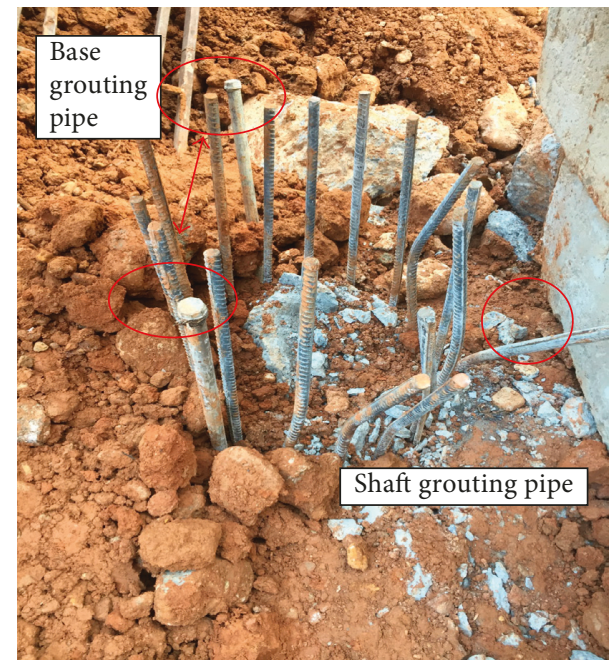

FIGURE 2: Base and shaft grouting system.

obtain the results of trial comparison, P51 was cast without any grouting. For the piles suffering from uplift force, uplift SLTs could have been conducted with P51, P121, and P126, but with consideration of loading influence from compressive SLTs, this team determined to cast the other two piles with labels of P15 and P16. The difference between these two piles was that P15 was applied with base and shaft grouting technology. The dynamic load tests were conducted on P121 and P126 for determination of load transfer behaviors.

\section{Tests Setup}

The SLTs were conducted based on the Chinese Technical Code for Testing of Building Foundation Piles [34]. According to this code, the maximum applied loads should be 2 times the designed loads with an increment value of 1/10 $L_{\mathrm{Max}}$ (e.g., for compressive SLTs: $L_{\mathrm{Max}}=2 \times 4500 \mathrm{kN}$; increment loading $=900 \mathrm{kN}$ ). As shown in Figures 3 and 4,

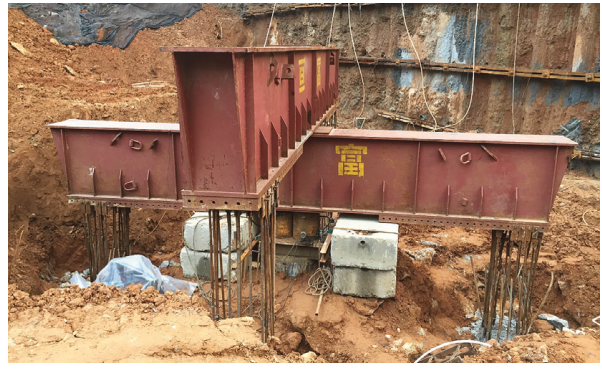

FIgURE 3: Compressive SLT setup.

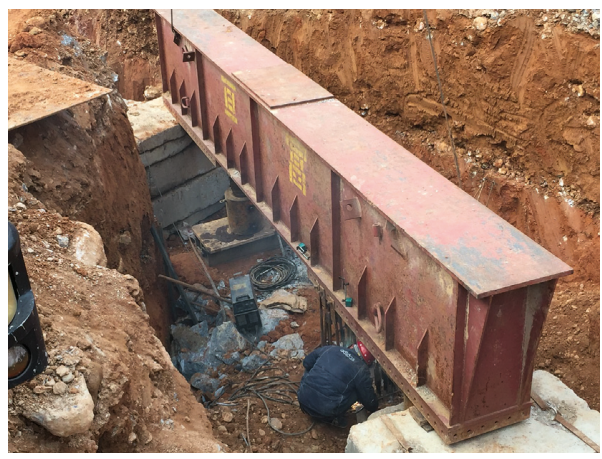

FIGURE 4: Uplift SLT4 setup.

four and two hydraulic jacks (QF630T-20) were used for providing loads to piles for compressive and uplift SLTs, respectively. The loading started from $1800 \mathrm{kN}$ with consecutive increments of $900 \mathrm{kN}$ and was released with decrements of $1800 \mathrm{kN}$ back to $0 \mathrm{kN}$ for the compressive SLTs (P51, P121, and P126); the loading started from $600 \mathrm{kN}$ with consecutive increments of $300 \mathrm{kN}$ and was released consecutively with decrements of $600 \mathrm{kN}$ back to $0 \mathrm{kN}$ for the uplift load tests (P15, and P16).

Similar to compressive loaded tests, for the uplift static load tests, low-speed maintenance tests were conducted. The applied load was maintained until the rate of axial movement did not exceed $0.1 \mathrm{~mm}$. Based on the requirement 


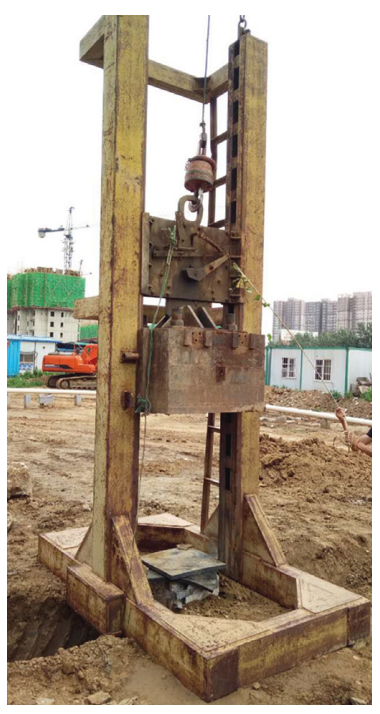

Figure 5: Dynamic load test setup.

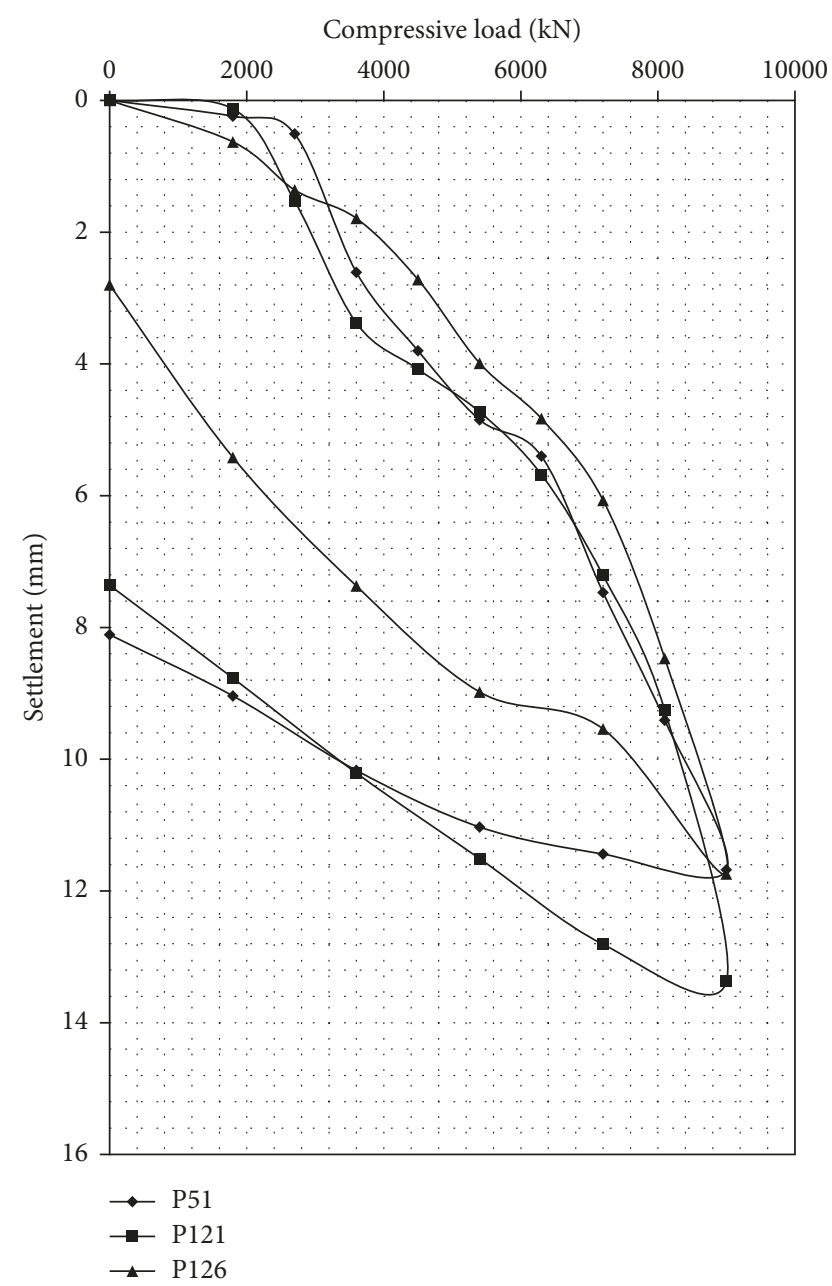

FIgURE 6: Results of compressive static load tests.

of the Chinese standard [34], after each load was applied, the vertical movement of piles was recorded at intervals of 5, 10, and 15 minutes, and at least 30 minutes was required if the

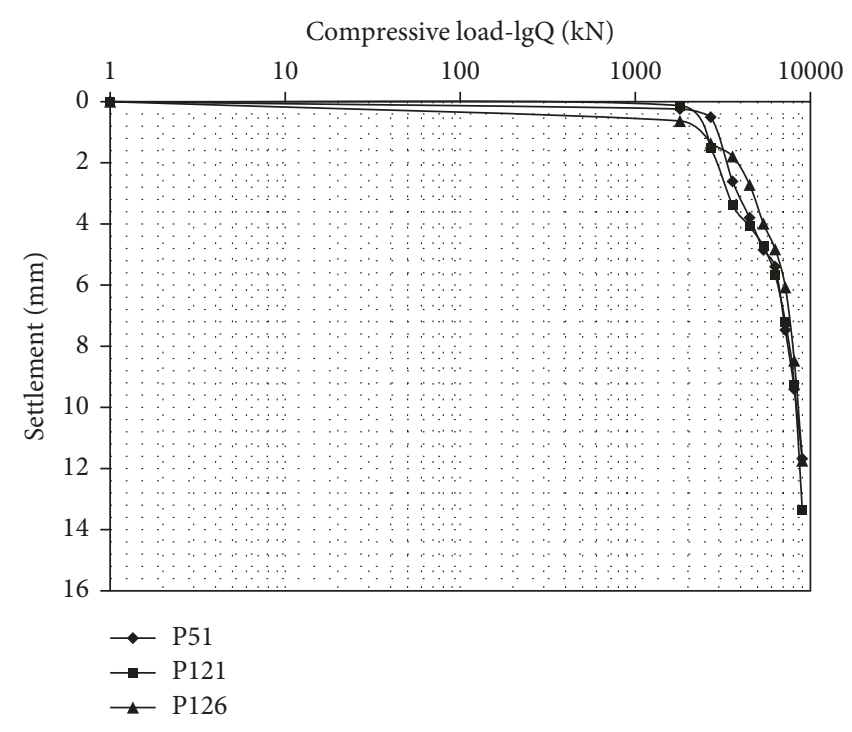

FIgURE 7: Results of S-lgQ curvatures.

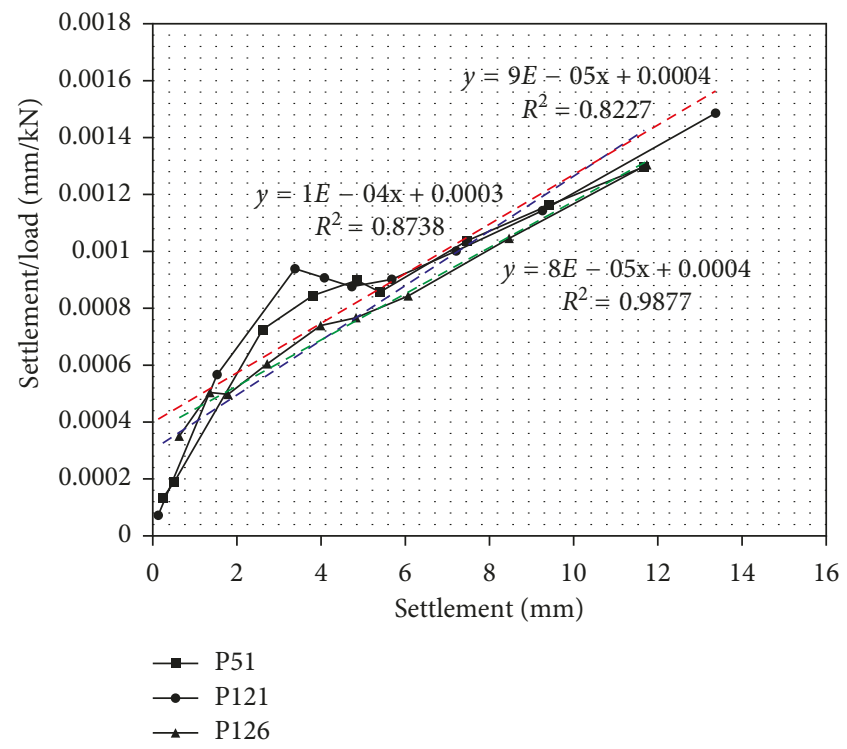

FIGURE 8: Results based on Chin's method.

accumulated time exceeded 1 hour. The loading could be terminated in the case of the following conditions: (1) the applied loading is equal to the value of 0.9 times the ultimate strength of reinforcement, (2) a quintuple movement change from the previous loading is discovered, or (3) pile head movement is increased up to $100 \mathrm{~mm}$.

The setup of dynamic load tests is illustrated in Figure 5. For this test, the dynamic penetration analyzer (PDA) (RS-1616K(S)) was used for signal analysis. Two accelerators (SY-2) and two strain transducers (CYB-YB-FIKA) were installed symmetrically onto the pile surface with a distance equal to or over the value of $2 \mathrm{D}$ (D-diameter of pile) from the pile head. The wave signal was recorded by accelerators and strain transducers after a heavy hammer punched onto the pile head, and the PDA matched the signal based on the CAPWAP program. 
TABLE 4: Pile capacity based on different methods.

\begin{tabular}{lcccccc}
\hline \multirow{2}{*}{ Pile label } & \multicolumn{2}{c}{ Double-tangent } & \multicolumn{2}{c}{ DeBeer's } & \multicolumn{2}{c}{ Chin's } \\
& Load $(\mathrm{kN})$ & Settlement $(\mathrm{mm})$ & Load $(\mathrm{kN})$ & Settlement $(\mathrm{mm})$ & Load $(\mathrm{kN})$ & Settlement $(\mathrm{mm})$ \\
\hline P51 & 7560 & 6.0 & 7600 & 7.9 & 10,000 & N/A \\
P121 & 7700 & 6.2 & 7900 & 8.3 & 11,111 & N/A \\
P126 & 8250 & 8.0 & 8300 & 8.2 & 12,500 & N/A \\
\hline
\end{tabular}

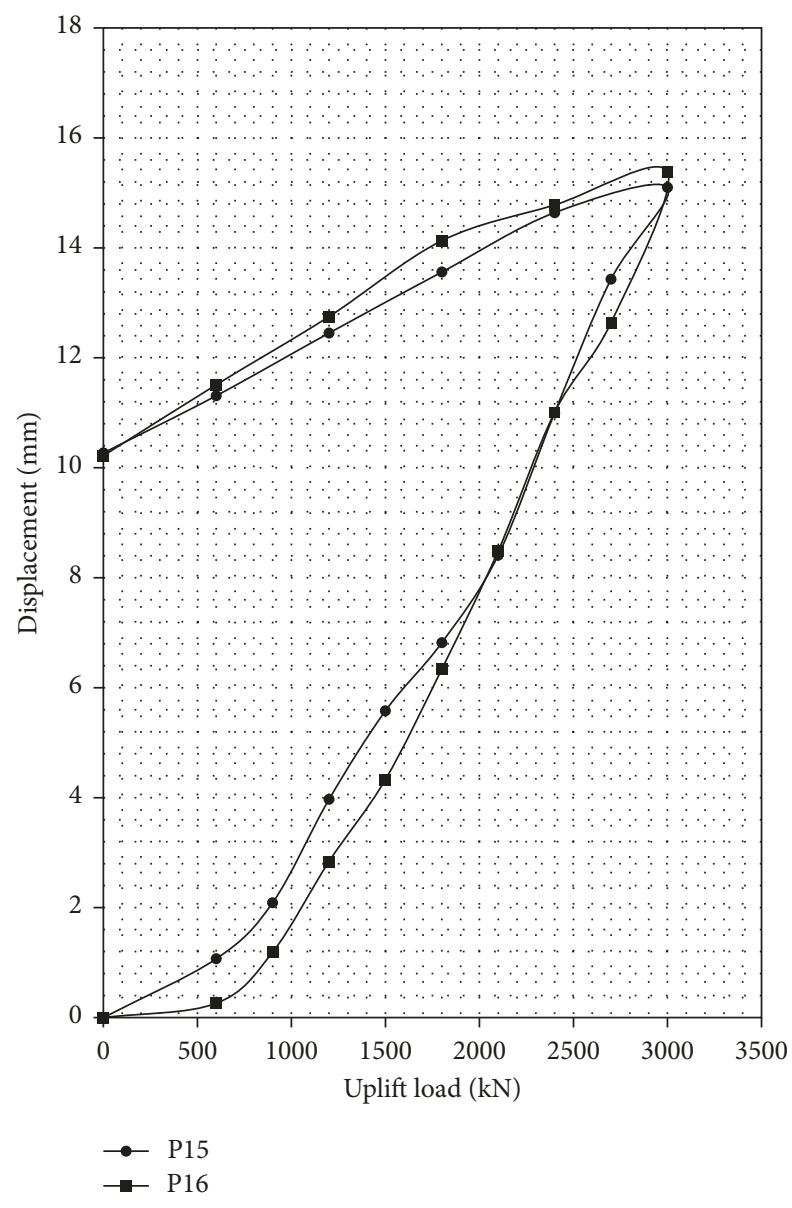

FIgURE 9: Results of uplift static load tests.

\section{Results and Discussion}

5.1. Results of Compressive SLTs. The load-settlement curves of three compressive loaded piles are provided in Figure 6; after the maximum loading of $9000 \mathrm{kN}$ is applied, the maximum settlements of pile heads are $11.68 \mathrm{~mm}, 13.37 \mathrm{~mm}$, and $11.74 \mathrm{~mm}$, respectively. The final settlements of P51 and P121 are discovered as $8.11 \mathrm{~mm}$ and $7.36 \mathrm{~mm}$, respectively. This is highly becasue the bearing stratum is diorite, which leads to a small settlement decrease after base grouting. P126 shows a smaller total settlement of $2.8 \mathrm{~mm}$. This demonstrates that the base and shaft grouting will decrease the final settlement of a pile foundation. The S-lgQ of these 3 compressive loaded piles is provided in Figure 7. Through S-lgQ curvatures, the ultimate compressive bearing capacities of piles can be determined, albeit with difficulty, to be $6800 \mathrm{kN}, 7100 \mathrm{kN}$, and $8000 \mathrm{kN}$, respectively. This is because

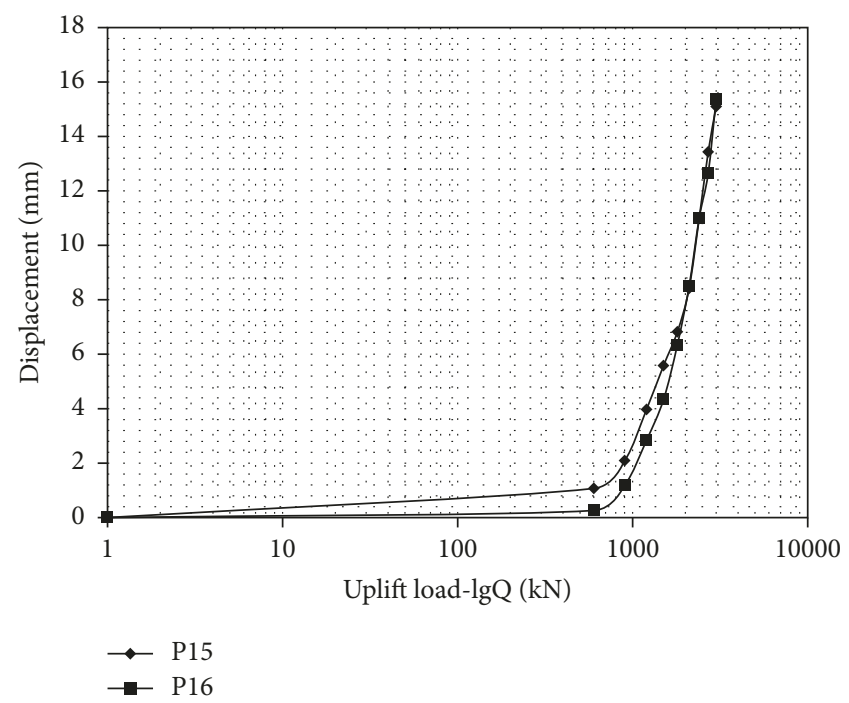

FIgURE 10: Results of S-lgQ curvature.

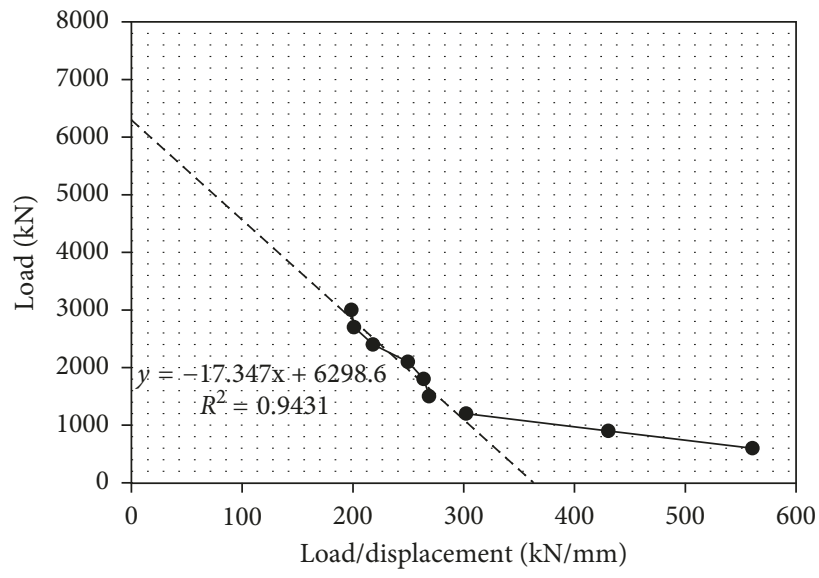

FIGURE 11: Uplift SLT result of P15.

the tests are "Prove Tests," which aim to ensure that the pile settlement is acceptable under the maximum loading (equal to twice the design load). All 3 pile foundations illustrate semielastic characteristics, and the nonfailure settlements lead to difficulty in determining the capacity from S-lgQ curves. The determination of ultimate pile capacity then needs more comprehensive analysis.

Another common method to plotting the failure criteria of drilled pile is the "double-tangent" method, emphasized by AASHTO (2002) and FHWA (1992c) [7]. In addition, it can also be performed by DeBeer's log-log method and 


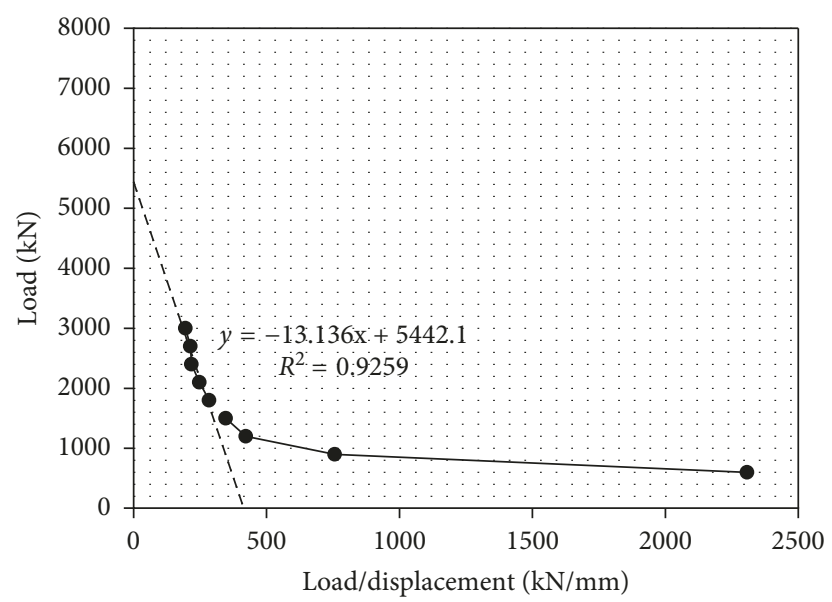

FIgURe 12: Uplift SLT result of P16.

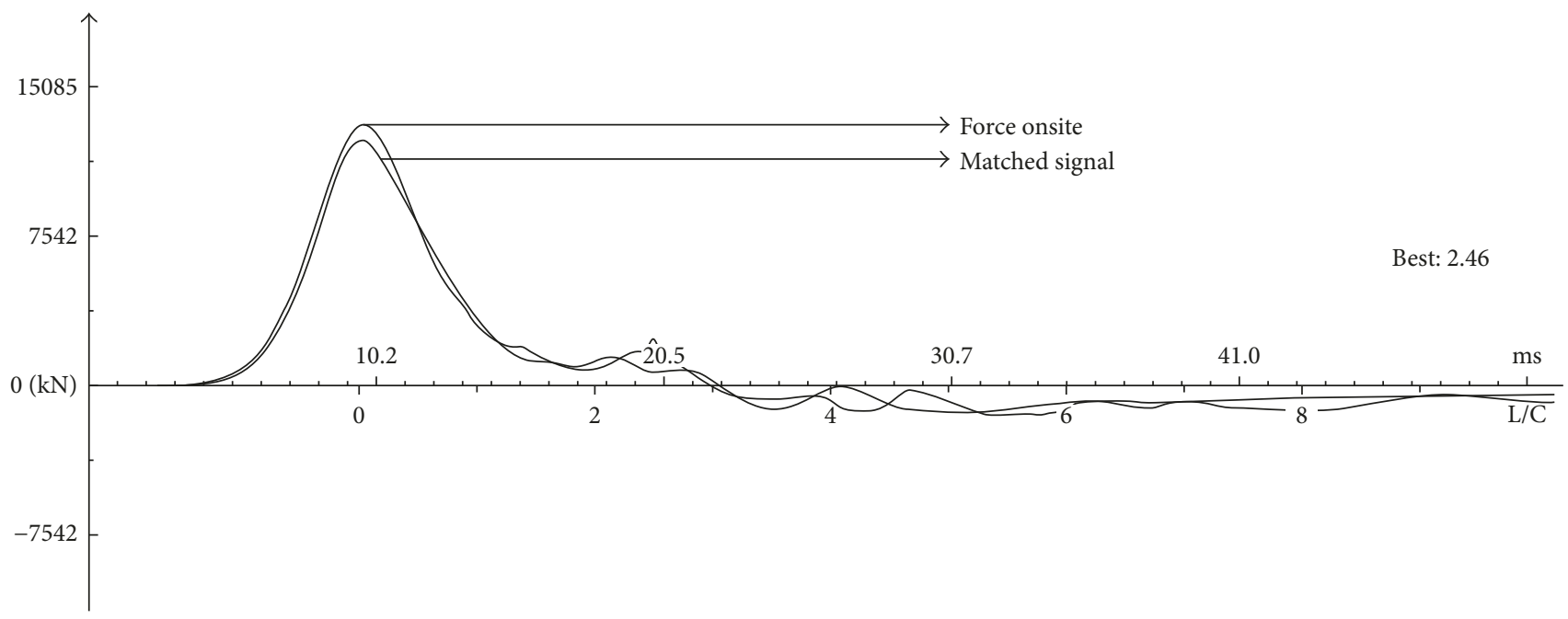

FIGURE 13: CAPWAP results of P121.

Chin's method. Through plotting data using logarithmic scales, the failure load and corresponded maximum vertical settlement can be determined [35]. Chin [36] assumed that the Q-s relationship is hyperbolic, and plotting $\Delta / \mathrm{P}$ versus load determines the bearing capacity of pile. As provided in (1), the inverse slope results in the failure value. The results of these three piles based on Chin's method are provided in Figure 8. Three functions are found, and the slopes of P51, P121, and P126 are determined as $1 \mathrm{E}-4,9 \mathrm{E}-5$, and $8 \mathrm{E}-5$, respectively. By determining two tangent lines in the Q-S curves of each pile, the intersection points which represent the ultimate capacity are determined, and by plotting the values from Q-s curves into lgQ-lgs curves (DeBeer's method), the capacity can be determined.

$$
\mathrm{Qu}=1 / C_{1} \text {, }
$$

where $Q u$ is the pile ultimate bearing capacity and $C_{1}$ is the slope of the plotted line.
Based on these methods, the bearing capacities as well as corresponding settlement of these 3 piles are summarized in Table 4. It can be seen that all interpretation methods illustrate that the pile capacity of base and shaft grouted pile is greater than that of the base grouted pile and that the capacity of piles with grouting technology is better than that of the traditionally treated pile. Because the double-tangent method and DeBeer's method are all aimed to find a point which can represent a "turning trend" through two tangent lines and logarithmic scales, the settlements determined from these two methods are close to each other as shown in Table 4.

5.2. Results of Uplift SLTs. In order to check if the piles achieved the design requirement when the piles suffered from uplift force and determine the improvement of base and shaft grouting techniques, two piles were selected for uplift static load tests with labels of P15 and P16. As shown in 


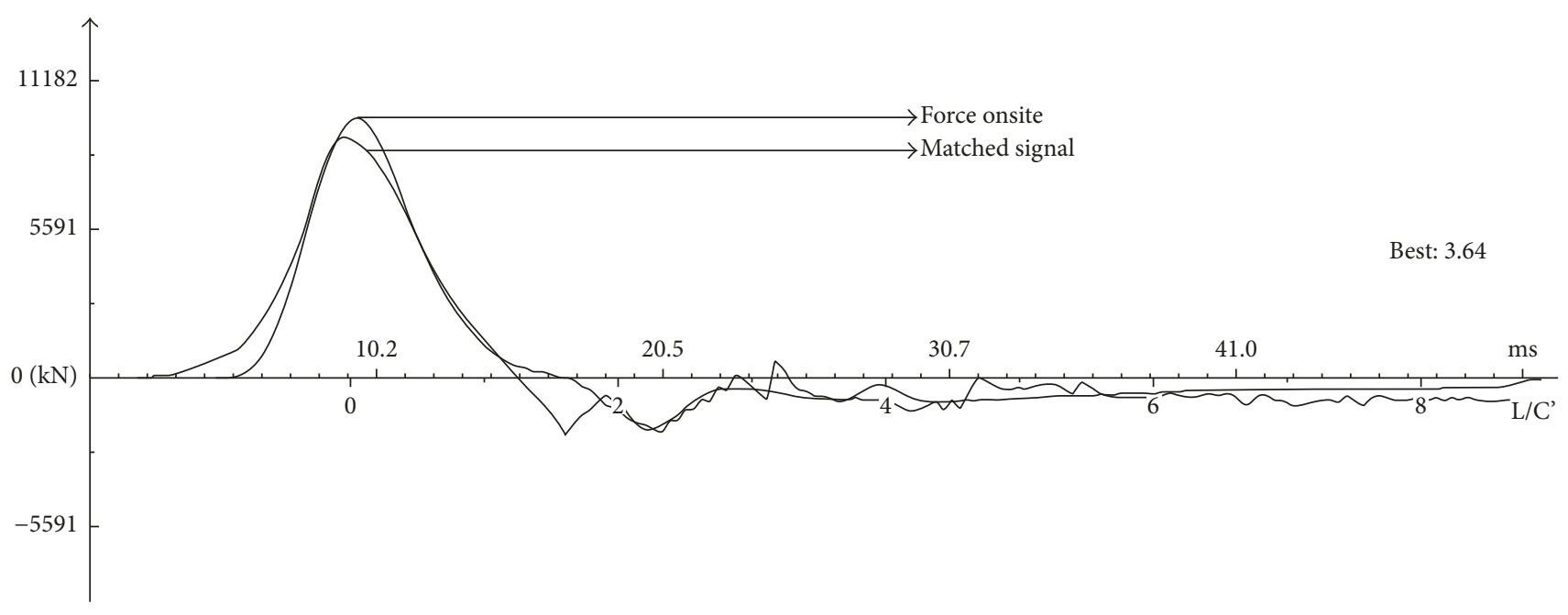

Figure 14: CAPWAP results of P126.

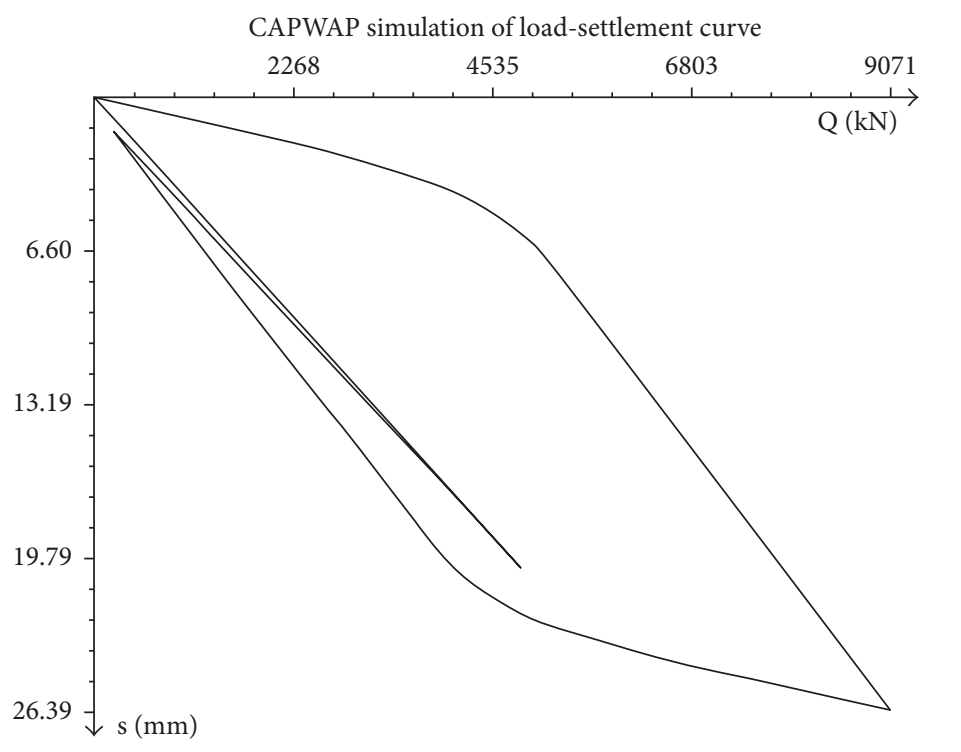

Maximum settlement: 26.37

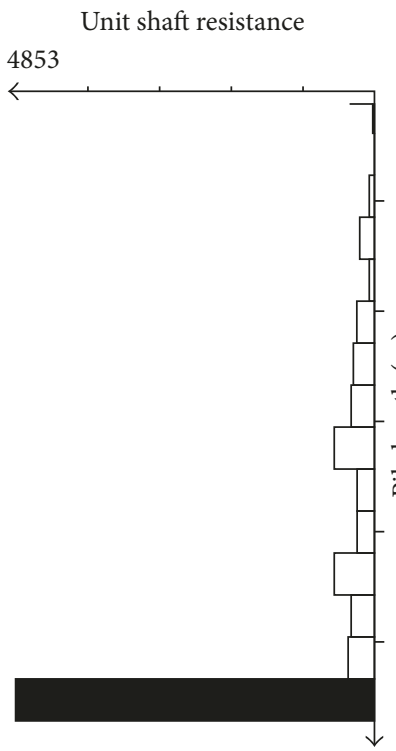

Shaft resistance: $4217.3 \mathrm{kN}$
Load transfer characteristic

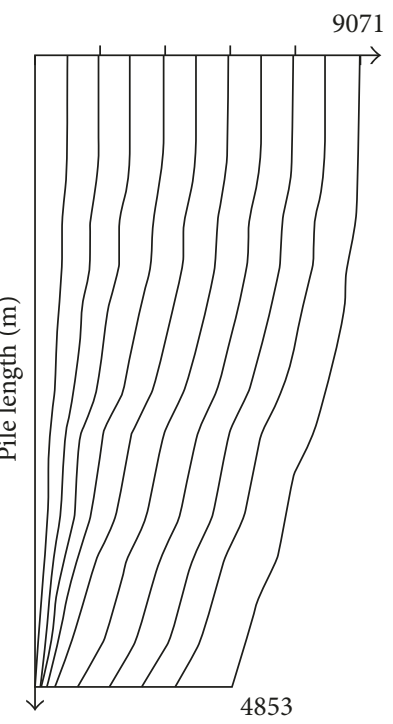

FIgURE 15: Simulated load-settlement curve, unit shaft resistance, and load transfer characteristic of P121.

Figure 9, when the maximum loading of $3000 \mathrm{kN}$ is applied, the maximum vertical movements of P15 and P16 are $15.1 \mathrm{~mm}$ and $15.38 \mathrm{~mm}$, respectively. It can be seen that before the loading value of $2500 \mathrm{kN}$, the vertical displacement of grouted pile is greater than that of the nongrouted pile; this phenomenon is highly caused by the disturbed soil layers that are not stable at a particular stage and then more loads applied. It also illustrates that when loading from $0 \mathrm{kN}$ to $3000 \mathrm{kN}$, the load lines demonstrate as linear. This illustrates that these two piles could resist more loading. By analyzing $S-\lg Q$ curves, it can be seen that there are no plunging points, as shown in Figure 10. This also illustrates that the pile achieves the designed load, but the maximum loading is not the ultimate bearing loading. Further research is required for ultimate bearing determination.
The ultimate uplift bearing capacity of nonfailure uplift SLTs can be determined by the modified Mazurkiewicz method [37]. The assumption is that when the nominate settlement (load/settlement) value is equal to 0 when the loading is small and the settlement is very high, a line would intersect with $y$-axis, which illustrates the uplift ultimate bearing capacity of pile. As shown in Figures 11 and 12, two functions are determined, and when $x=0$, the ultimate uplift bearing capacities of P15 and P16 are $6299 \mathrm{kN}$ and $5442 \mathrm{kN}$, respectively.

5.3. Dynamic Load Tests. Two dynamic load tests were conducted on piles of P121 and P126. Through CAPWAP programs, via many trials, the final matched signals are 


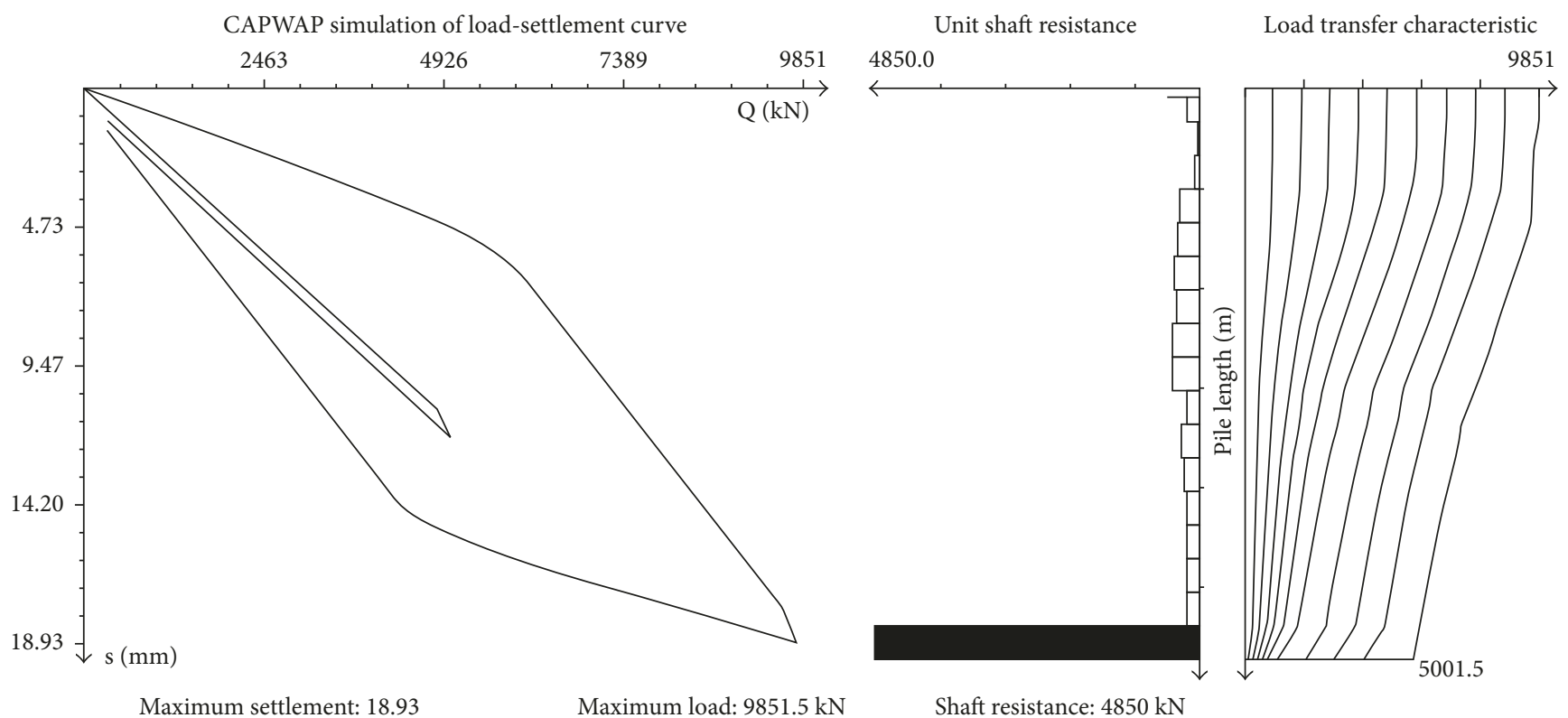

FIGURE 16: Simulated load-settlement curve, unit shaft resistance, and load transfer characteristic of P126.

TABLE 5: Static and dynamic load tests of compressive loaded piles.

\begin{tabular}{|c|c|c|c|c|c|c|c|c|c|}
\hline \multirow{2}{*}{$\begin{array}{l}\text { Pile } \\
\text { label }\end{array}$} & \multirow[b]{2}{*}{ Technology used } & \multicolumn{2}{|c|}{ Double-tangent } & \multicolumn{2}{|c|}{ DeBeer's } & \multicolumn{2}{|c|}{ Chin's } & \multicolumn{2}{|c|}{ Dynamic load test } \\
\hline & & $\begin{array}{l}\text { Load } \\
(\mathrm{kN})\end{array}$ & $\begin{array}{l}\text { Settlement } \\
\quad(\mathrm{mm})\end{array}$ & $\begin{array}{l}\text { Load } \\
(\mathrm{kN})\end{array}$ & $\begin{array}{l}\text { Settlement } \\
\quad(\mathrm{mm})\end{array}$ & $\begin{array}{l}\text { Load } \\
(\mathrm{kN})\end{array}$ & $\begin{array}{l}\text { Settlement } \\
(\mathrm{mm})\end{array}$ & $\begin{array}{l}\text { Load } \\
(\mathrm{kN})\end{array}$ & $\begin{array}{l}\text { Settlement } \\
(\mathrm{mm})\end{array}$ \\
\hline P51 & No grouting & 7560 & 6.0 & 7600 & 7.9 & 10,000 & N/A & $\mathrm{N} / \mathrm{A}$ & $\mathrm{N} / \mathrm{A}$ \\
\hline P121 & Base grouting & 7700 & 6.2 & 7900 & 8.3 & 11,111 & N/A & 9071 & 26.37 \\
\hline P126 & Base and shaft grouting & 8250 & 8.0 & 8300 & 8.2 & 12,500 & N/A & 9851.5 & 18.93 \\
\hline
\end{tabular}

TABLE 6: Static and dynamic load tests of uplift loaded piles.

\begin{tabular}{lcccc}
\hline \multirow{2}{*}{ Technology used } & \multicolumn{2}{c}{ Dynamic load test $(\mathrm{kN})$} & \multicolumn{2}{c}{ Mazurkiewicz's method $(\mathrm{kN})$} \\
& Ultimate bearing load & Shaft resistance & Ultimate bearing load & Shaft resistance \\
\hline No grouting & N/A & N/A & 5442 & 5442 \\
Base grouting & 9071 & 4217.3 & N/A & N/A \\
Base and shaft grouting & 9851.5 & 4850.0 & 6299 & 6299 \\
\hline
\end{tabular}

provided in Figures 13 and 14. Based on these two matched signals, the simulated load-settlement curves, the unit shaft resistance along the pile length, and load transfer characteristics are provided in Figures 15 and 16. Through dynamic load tests results, the ultimate bearing capacities of P121 and P126 are $9071 \mathrm{kN}$ and $9851.5 \mathrm{kN}$ with corresponding maximum settlements of $26.37 \mathrm{~mm}$ and $18.93 \mathrm{~mm}$, respectively. As shown in Figure 15, the shaft resistance of base grouted pile is not uniformly distributed along the pile, and compared to the results as illustrated in Figure 16, shaft grouting technology changed the shaft resistance and showed a relatively uniform distribution. This phenomenon occurred because shaft grouting changed the property of soil from pile shaft. It can also be seen that the shaft resistances of P121 and P126 are
$4217.3 \mathrm{kN}$ and $4850.0 \mathrm{kN}$, respectively. From the load transfer characteristic diagrams, it can be determined that load decreased along the pile length but increased with increasing applied loads. From comparison of load transfer characteristic diagrams between Figures 15 and 16, it can also be found that the shaft grouting increased the shaft resistance of the pile.

All tested pile results are summarized in Tables 5 and 6 . As shown in Table 5, all results obtained from different methods demonstrate that the base grouting and base and shaft grouting improve the ultimate bearing capacity of the piles. For instance, based on DeBeer's method, the capacity of base and shaft grouting pile (P126) is $8250 \mathrm{kN}$, and the base grouting pile of $\mathrm{P} 121$ is $7700 \mathrm{kN}$; these two values are all greater than the no grouting pile P51, where 
capacity is $7560 \mathrm{kN}$. This is because the grouting technique increases the shaft and base area to resist the compressive working loads. In addition, it can also be seen that the ultimate load and settlement acquired from the doubletangent method is close to the outcome obtained from DeBeer's method. Furthermore, the results obtained from Chin's method and dynamic methods are relatively close to each other.

For the friction resistance analysis of uplift load tests and compressive dynamic load tests, Table 6 demonstrates that base and shaft grouted piles possess better capacity than the base grouted piles $(4850.0>4217.3)$ and piles without grouting $(6299>5442)$. The phenomenon is caused by the postgrouting technique, which increases the total friction area between concrete surface and soil layers. It can also be seen that the grouting technique can improve shaft capacity as well as the end bearing capacity of piles (9851.5-4850.0 > 9071-4217.3). Furthermore, compared to the shaft resistance results obtained from dynamic load tests, Mazurkiewicz's method overestimates the ultimate capacity of uplift loaded piles.

\section{Conclusions}

This paper provides the setup of static and dynamic load tests and various methodologies which are used to determine the ultimate compressive and uplift bearing capacity under nonplunging failure conditions. It illustrates that the results from double-tangent and DeBeer's methods are close to each other and that the results from Chin's and dynamic methods are close to each other.

Compared to the ultimate compressive static load tests' results, it shows that the base and shaft grouting pile increases about $9.82 \%$ of its capacity without any grouting. The base grouting pile increases approximately $2.89 \%$ of its capacity without grouting. Furthermore, the capacity of the shaft and base grouted pile increases $6.1 \%$ of the base grouting pile, and this value is close to results obtained from dynamic load tests $(8.6 \%)$.

By comparing the ultimate uplift static load test results, it can be determined that there is a $15.7 \%$ increment of ultimate pile capacity and shaft capacity after using base and shaft grouting technology. Compared to the shaft resistance capacities of base grouted piles with base and shaft grouted piles obtained from dynamic load test, a $15.0 \%$ increment is demonstrated.

This paper also provides the load transfer characteristic of piles obtained from dynamic load tests. Because the base grouting and shaft grouting techniques were the same, these tests were conducted without consideration of grouting materials and pressure. Further study should be initiated focusing on the influence of various materials, grouting pressure, and proportion of the grouting material to determine the best way to increase pile capacity.

\section{Conflicts of Interest}

The authors declare that there are no conflicts of interest regarding the publication of this paper.

\section{References}

[1] R. J. Castelli and E. Wilkins, "Osterberg load cell test results on base grouted bored piles in Bangladesh," in Proceedings of the GeoSupport 2004: Drilled Shafts, Micropiling, Deep Mixing, Remedial Methods, and Specialty Foundation Systems, pp. 587-602, Orlando, FL, USA, December 2004.

[2] D. Patel, S. Glover, J. Chew, and J. Austin, "The Pinnacledesign and construction of large diameter deep base grouted piles in London," Ground Engineering, pp. 24-31, 2015.

[3] M. Tomlinson and J. Woodward, Pile Design and Construction Practice, CRC Press, London, UK, 2007.

[4] C. Shi, "The application of the pile-end mud-jacking technique used in the construction of bored caisson pile," SCI/TECH Information Development \& Economy, vol. 15, no. 23, pp. 293-296, 2005.

[5] X. Li, K. Xie, G. Zeng, and X. Hou, "Research of bored pile slurry effect created during construction," Structural Construction, vol. 30, no. 5, pp. 21-23, 2000.

[6] S. Dapp, M. Muchard, and D. Brown, "Experiences with basegrouted drilled shafts in the South-eastern United States," in Proceedings of 10th International Conference on Piling and Deep Foundations, pp. 1-10, Deep Foundations Institute, Amsterdam, Netherlands, 2006.

[7] N. C. Samtani and E. A. Nowatzki, Soils and Foundations: Reference Manual-Volume II, pp. 1-568, U.S. Department of Transportation, Washington, DC, USA, 2006.

[8] A. Zhussupbekov and A. Omarov, "Modern advances in the field geotechnical testing investigations of pile foundations," Procedia Engineering, vol. 165, pp. 88-95, 2016.

[9] C. E. Ho, "Base grouted bored pile on weak granite," in Proceedings of the Grouting and Ground Treatment, pp. 716727, New Orleans, LA, USA, February 2003.

[10] K. M. Rollins, K. H. Kwon, and T. M. Gerber, "Static and dynamic lateral load tests on a pile cap with partial gravel backfill," in Geotechnical Earthquake Engineering and Soil Dynamics IV, pp. 1-6, Sacramento, CL, USA, May 2008.

[11] N. Thasnanipan, W. Teparaksa, A. W. Maung, and G. Baskaran, "Design, construction and behavior of bored cast in-situ concrete piles in bangkok sub soil," in Proceedings of Fourth International Conference on Case History in Geotechnical Engineering, pp. 218-287, St. Louis, MI, USA, March 1998.

[12] D. Wang, L. Wang, and L. Zhang, "Experimental study on post grouting bearing capacity of large diameter bored piles," MATEC Web of Conferences, vol. 22, pp. 1-7, 2015.

[13] W. Wang, J. Wu, and G. Di, "Performance of base grouted bored piles in specially big excavation constructed using topdown method," in Proceedings of Underground Construction and Ground Movement, pp. 393-400, Shanghai, China, June 2006.

[14] V. L. Nguyen, L. Nie, and M. Zhang, "Method cement postgrouting to increase the load capacity for bored pile," Research Journal of Applied Sciences, Engineering and Technology, vol. 5, no. 19, pp. 4727-4732, 2012.

[15] B. Wang and J. Zhang, "Mechanical mechanism of the post-grouting pile," Applied Mechanics and Materials, vol. 351-352, pp. 510-514, 2013.

[16] R. K. Zhang, M. L. Shi, H. Zhang, and J. Wang, "The enhancement effect analysis of pile-base post-grouting piles," Applied Mechanics and Materials, vol. 170-173, pp. 227-231, 2012.

[17] S. Thiyyakkandi, M. McVay, D. Bloomquist, and P. Lai, "Measured and predicted response of a new jetted and grouted 
precast pile with membranes in cohesionless soils," Journal of Geotechnical and Geoenvironmental Engineering, vol. 139, no. 8, pp. 1334-1345, 2013.

[18] J. Sinnreich and R. C. Simpson, "Base grouting case studies including full scale comparative load testing," in Proceedings of the 7th International Conference on Case Histories in Geotechnical Engineering, Chicago, IL, USA, April-May 2013.

[19] K. C. Huo, X. Qin, and H. H. Yue, "Research on uplift static load test of large-diameter steel pipe pile based on mechanics," Applied Mechanics and Materials, vol. 256-259, pp. 410-415, 2013.

[20] O. Kusakabe, M. Kakurai, K. Ueno, and Y. Kurachi, "Structural capacity of precast piles with grouted base," Journal of Geotechnical Engineering, vol. 120, no. 8, pp. 1289-1306, 1994.

[21] A. Shelke and N. Patra, "Effect of compressive load on uplift capacity of cast-insitu bored piles," Geotechnical and Geological Engineering, vol. 29, no. 5, pp. 927-934, 2011.

[22] K. E. Gaaver, "Uplift capacity of single piles and pile groups embedded in cohesionless soil," Alexandria Engineering Journal, vol. 52, no. 3, pp. 365-372, 2013.

[23] S. Thiyyakkandi, M. McVay, D. Bloomquist, and P. Lai, "Experimental study, numerical modeling of and axial prediction approach to base grouted drilled shafts in cohesionless soils," Acta Geotechnica, vol. 9, no. 3, pp. 439-454, 2014.

[24] A. Verma and R. K. Joshi, "Uplift load carrying capacity of piles in sand," in Proceedings of Indian Geotechnical Conference, pp. 858-860, Mumbai, India, 2010.

[25] K. Madhusudan Reddy and R. Ayothiraman, "Experimental studies on behavior of single pile under combined uplift and lateral loading," Journal of Geotechnical and Geoenvironmental Engineering, vol. 141, no. 7, p. 4015030, 2015.

[26] H. Moayedi and M. Mosallanezhad, "Uplift resistance of belled and multi-belled piles in loose sand," Measurement, vol. 109, pp. 346-353, 2017.

[27] J. Zhou, E. Oh, X. Zhang, H. Jiang, M. Bolton, and P. Wang, "Compressive and uplift static load tests of shaft and base grouted concrete bored piles," in Proceedings of 27th International Ocean and Polar Engineering Conference, pp. 685-692, San Francisco, CA, USA, 2017.

[28] G. S. Budi, M. Kosasi, and D. H. Wijaya, "Bearing capacity of pile foundations embedded in clays and sands layer predicted using PDA test and static load test," Procedia Engineering, vol. 125, pp. 406-410, 2015.

[29] G. Likins, F. Rausche, G. Thendean, and M. Svinkin, "CAPWAP correlation studies," in Proceedings of the Fifth International Conference on the Application of Stress-Wave Theory to Piles, pp. 447-455, Orlando, FL, USA, September 1996.

[30] B. Robinson and M. Iskander, "Static and dynamic load tests on driven polymeric piles," in Proceedings of the Geo Congress 2008: Geosustainability and Geohazard Mitigation, pp. 939946, New Orleans, LA, USA, March 2008.

[31] T. A. Tolosko, Extrapolation of Pile Capacity from Non-Failed Load Tests, pp. 1-157, ProQuest Dissertations Publishing, McLean, VA, USA, 1999.

[32] GB50021-2001, Code for Investigation of Geotechnical Engineering, China Building Industry Press, Beijing, China, 2001.

[33] GB/T 50123-1999, Standard for Soil Test Method-GB/T 50123, Ministry of Construction of People's Republic of China, Beijing, China, 1999.

[34] JGJ106-2014, Technical Code for Testing of Building Foundation Piles, China Architecture \& Building Press, Beijing, China, 2014.
[35] E. DeBeer, "Proefondervindellijke bijdrage tot de studie van het grandsdraagvermogen van zand onder funderinger op staal," Tijdshift der Openbar Verken van Belgie, vol. 20, no. 4, pp. 387-411, 1970.

[36] F. K. Chin, "Estimation of the ultimate load of piles from tests not carried to failure," in Proceedings of the 2nd Southeast Asian Conference on Soil Engineering, pp. 81-90, Singapore, June 1970.

[37] K. Thanadol, Study of Pile Capacity from Ultimate Pile Load Test, Kasetsart University, Bangkok, Thailand, 1998. 


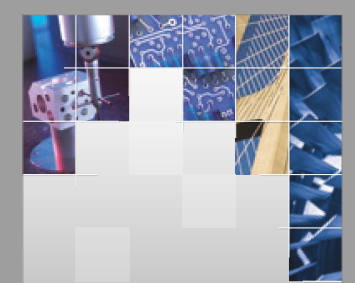

\section{Enfincering}
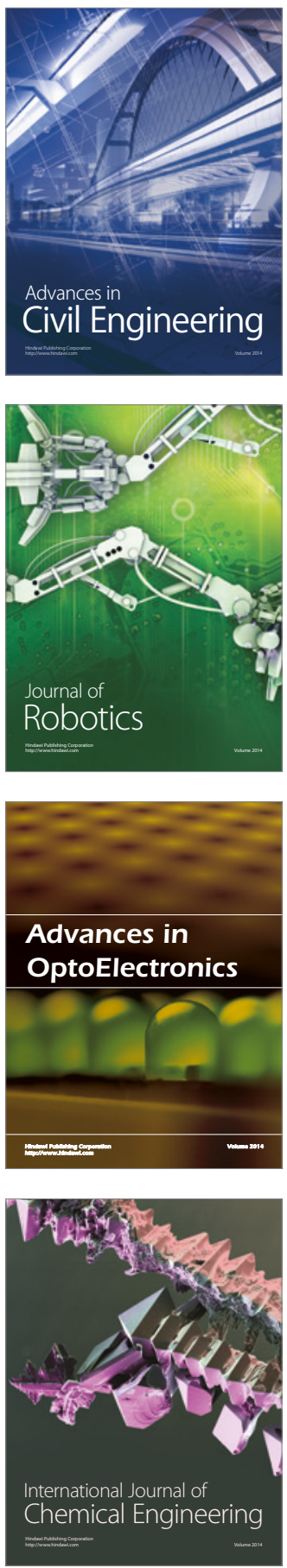

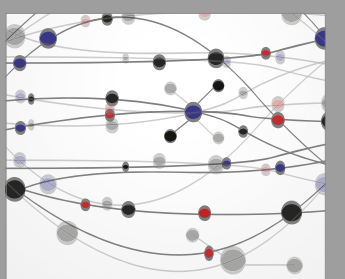

The Scientific World Journal

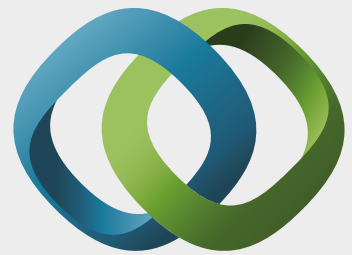

\section{Hindawi}

Submit your manuscripts at

https://www.hindawi.com
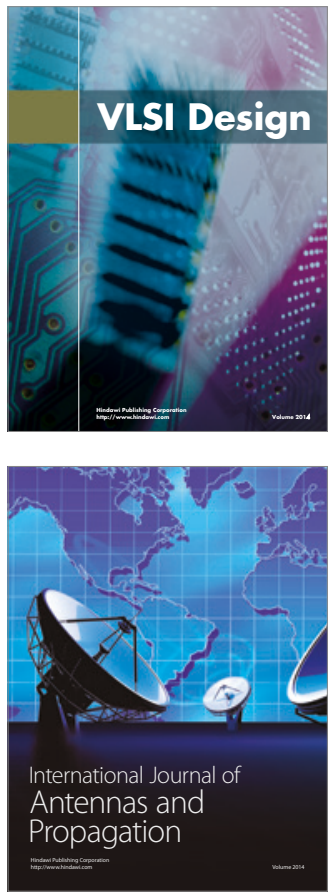

\section{Rotating}

Machinery
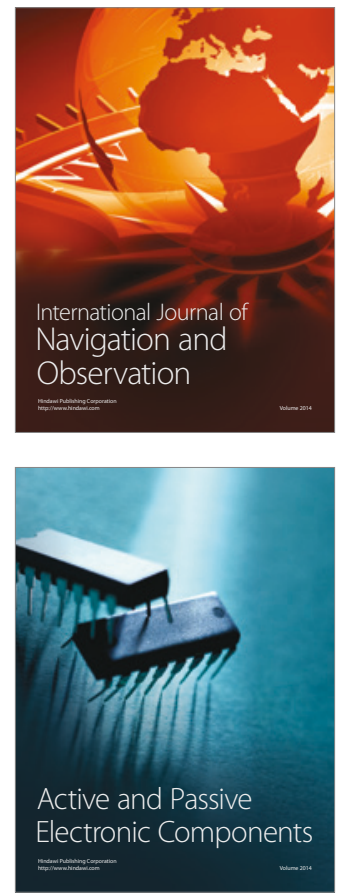
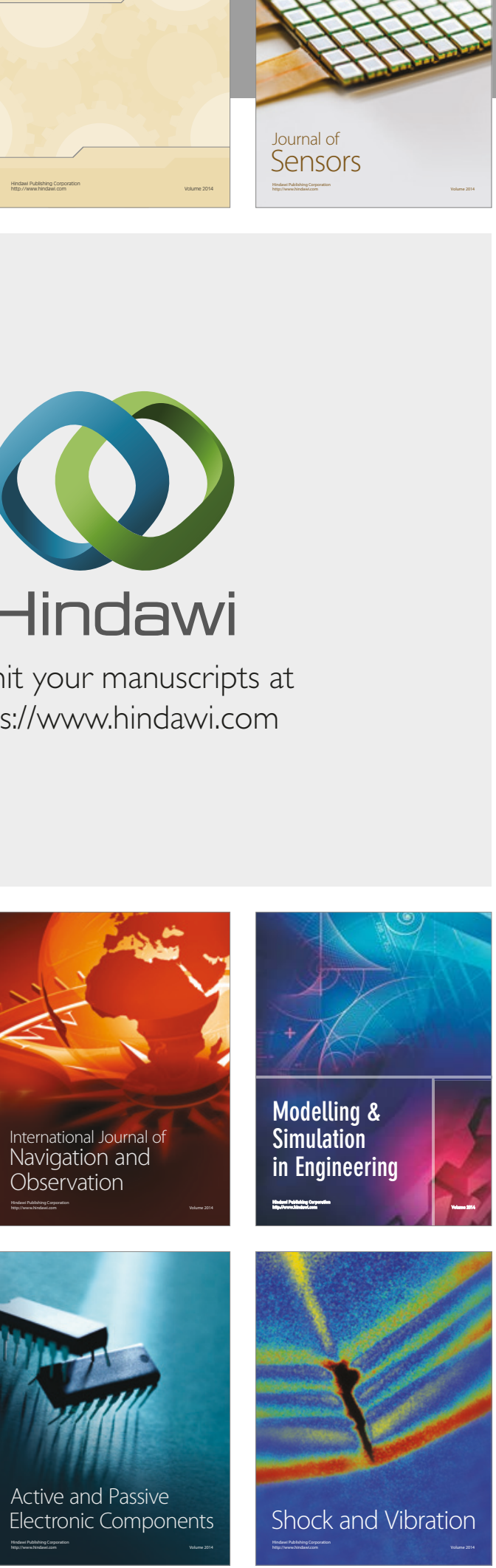
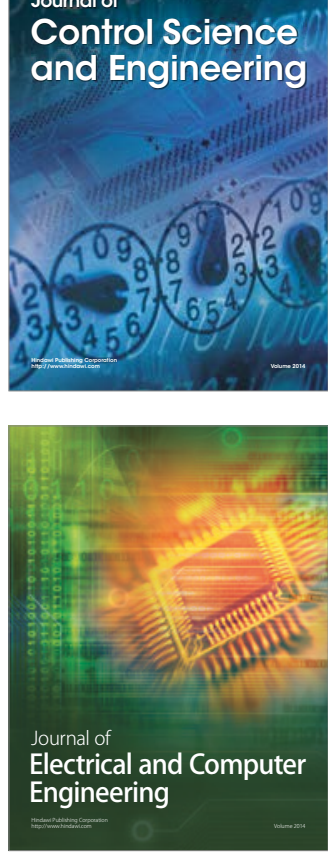

Distributed

Journal of

Control Science

and Engineering
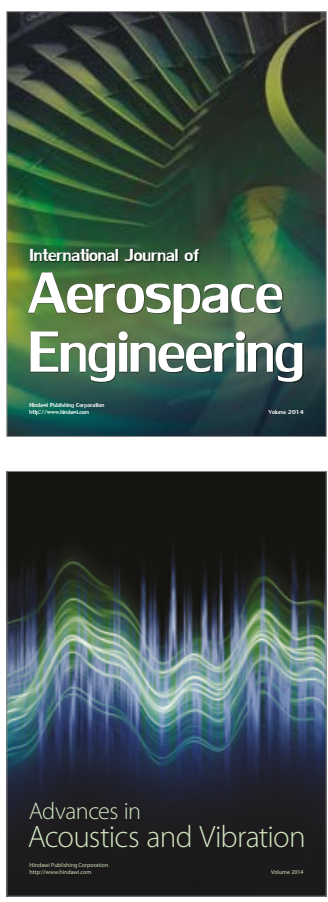

Sensor Networks 